\title{
PENGUJIAN MESIN DIESEL YANG DIMODIFIKASI MENJADI BERBAHAN BAKAR GAS LPG
}

\author{
Himsar Ambarita \\ Jurusan Teknik Mesin, Universitas Sumatera Utara \\ JI. Almamater Kampus USU Medan 20155 \\ Email: himsar@usu.ac.id
}

\begin{abstract}
ABSTRAK
Pada penelitian ini dilakukan modifikasi pada sebuah mesin diesel yang awalnya digerakkan dengan menggunakan bahan bakar diesel menjadi berbahan bakar LPG. Telah dirancang suatu alat uji yang menggunakan sebuah mesin diesel silinder tunggal dengan daya 2,5 kW dan 2,8 kW pada putaran mesin 3000 dan $3600 \mathrm{rpm}$. Kinerja mesin diesel kecil telah diuji dalam dua bahan bakar berbeda yaitu solar dan LPG. Pada penggunaan bahan bakar solar tidak ada perubahan yang dilakukan pada mesin disel. Pada penggunaan bahan bakar LPG mesin diubah menjadi mesin pengapian percikan dengan mengganti pompa oli menjadi busi. Dilihat dari unjuk kerja mesin yang dijalankan pada bahan bakar LPG sebanding dengan putaran mesin pada bahan bakar diesel. Namun, konsumsi bahan bakar spesifik dari mesin dengan bahan bakar LPG rata-rata 17,53\% lebih tinggi pada beban $800 \mathrm{~W}$, jika dibandingkan dengan mesin yang dijalankan dengan bahan bakar diesel. Disarankan untuk meningkatkan efisiensi mesin yang dioperasikan dengan bahan bakar LPG dengan modifikasi lebih lanjut dalam rasio kompresi dan sistem injeksi bahan bakar yang lebih baik.
\end{abstract}

Kata kunci: Mesin Diesel, Bahan Bakar Solar dan LPG.

\section{PENDAHULUAN}

Emisi Gas Rumah Kaca (GRK) diperkirakan akan menjadi masalah yang sangat besar di masa yang akan datang. GRK yang terlalu banyak di atmosfer akan menaikkan suhu rata-rata permukaan bumi dan akan menjadi bencana yang mengancam keberlangsungan kehidupan di muka bumi. Untuk menghindari bumi dari kehancuran, banyak negera telah mengumumkan komitmen untuk menurunkan emisi GRKnya. Indonesia telah mengumumkan komitmennya dalam menurunkan emisi GRK sebesar 26\% dari kondisi Business-as-Usual (BAU) pada tahun 2020 dengan usaha sendiri dan dapat menjadi $41 \%$ dengan adanya bantuan luar. Komitmen ini kemudian diubah lagi menjadi 29\% pada tahun 2030 [1]. Salah satu sumber emisi GRK yang terbesar adalah sektor energi, dimana terjadi pembakaran dari bahan bakar berbasis fosil untuk menhasilkan energi yang mendukung kegiatan manusia, seperti menggerakkan mesin mesin. Target pengurangan emisi dari sektor energi ini adalah sebesar 314 juta ton $\mathrm{CO}_{2 \mathrm{e}}$ atau sebesar $11 \%$ dari target total pengurangan emisi pada tahun 2030 [2]. Salah satu jenis mesin yang banyak menghasilkan emisi GRK adalah mesin diesel. Mesin diesel banyak digunakan pada alat-alat berat, transportasi, industri dan mesin pertanian. Strategi pengurangan emisi pada mesin diesel akan memberikan kontribusi yang signifikan bagi usaha mengurangi emisi GRK [3].

Mengurangi emisi GRK pada mesin diesel dapat dilakukan dengan dua cara. Pertama menggunakan teknologi bahan bakar ganda. Pada metode ini, bahan bakar diesel dikurangi dan digantikan dengan bahan bakar gas. Metode kedua adalah dengan melakukan modifikasi mesin diesel agar dapat digerakkan dengan menggunakan bahan bakar gas. Pada metode ini, mesin diesel yang awalnya dioperasikan dengan sistem pembakaran kompresi (compression ignition engine) 
menjadi mesin dengan pembakaran api (spark ignition engine). Setelah dilakukan modifikasi, bahan bakar mesin dapat diganti menjadi gas yang lebih rendah emisinya seperti Biogas atau gas LPG.

Penelitian ini fokus pada teknologi modifikasi mesin diesel menjadi berbahan bakar gas. Beberapa peneliti telah melakukan penelitian yang bertujuan mempelajari karakteristik mesin diesel yang digerakkan oleh bahan bakar gas. Chandra dkk. [4] melakukan penelitian tentang kajian performansi mesin diesel stasioner berdaya 5,9 kW yang dimodifikasi menjadi berbahan bakar gas. Kemudian mesin tersebut diuji pada 3 bahan bakar yang berbeda, yaitu compressed natural gas (CNG), biogas yang diperkaya dengan metan (Bio-CNG), dan biogas yang berasal dari Jatropha dan Pongamia. Hasilnya menunjukkan mesin dengan bahan bakar Bio-CNG memberikan performansi yang hampir sama dengan CNG. Performansi dinyatakan dengan daya luaran (brake output power), konsumsi gas spesifik (specific fuel consumption atau $s f c$ ), dan efisiensi thermal. Lee [5] melakukan kajian eksperimental pada sebuah mesin diesel $30 \mathrm{~kW}$ yang diubah menjadi berbahan biogas. Modifikasi tambahan yang digunakan adalah melakukan pemanasan awal (preheating) terhadap udara yang masuk ruang bakar dengan memanfaatkan panas dari gas buang (heat recovery system). Parameter yang diuji adalah perbedaan temperatur udara masuk yang dipanasi yang dipanasi. Hasil pengujian menunjukkan daya luaran meningkat dengan meningkatnya konsentrasi metan di dalam biogas, kecuali pada rasio kelebihan udara (excess air ratio) kurang dari 0.85 . Pada rasio kelebihan udara lebih besar dari 0.95, efisiensi thermal mesin meningkat dengan meningkatnya konsentrasi metan pada biogas.

Tetapi pada konsentrasi yang sangat tinggi tidak muncul keuntungan yang nyata. Peningkatan performansi mesin yang didapat sebagai akibat dari pemanasan awal akan nyata saat rasio kelebihan udara tinggi, atau lebih dari 1,3.

Homdoung dan Tippayawong [6] melakukan modifikasi pada mesin diesel yang digunakan pada pertanian dan dioperasikan dengan bahan bakar gas. Jenis mesin yang digunakan adalah satu silinder, empat langkah, sistem injeksi tidak langsung, volume silinder $598 \mathrm{cc}$ dan rasio kompresi 22. Modifikasi yang dilakukan adalah mengubah sistem pembakaran menjadi sistem spark. Hasil pengujian menunjukkan efisiensi termal brake dapat mencapai 23,9\%. Analaysis gas buang menunjukkan kepadatan asap gas buang lebih rendah daripada saat dioperasikan dengan bahan bakar solar. Tetapi kandungan $\mathrm{CO}$ dan Hydrokarbon lebig tinggi.

Kemudian Poompipatpong dan Cheenkachorn [7] melakukan pengujian performansi dan emisi gas buang dari sebuah mesin diesel yang dimodifikasi dan digerakkan dengan bahan bakar gas alam. Mesin diuji pada beberapa rasio kompresi (CR) mulai dari 1:1, 9,5:1, 10:1 dan 10,5:1. Pengujian dilakukan pada putaran 1000 dan 4000 rpm. Hasil pengujian menunjukkan pada CR 9,5:1 mesin menghasilkan efisiensi termal tertinggi dan nilai $s f c$ terendah. Sementara pada CR 10:1 menunjukkan torsi tertinggi pada kecepatan yang rendah. Emisi total hidrokarbon (HC) sebanding dengan CR. Emisi $\mathrm{NO}_{\mathrm{x}}$ meningkat dengan peningkatan $\mathrm{CR}$ dan kemudian menurun menurun setelah $\mathrm{CR}$ 10:1. Bedoya dkk [8] melakukan kajian eksperimental untuk melakukan evaluasi strategi untuk meningkatkan sebaran operasi mesin diesel tipe $\mathrm{HCCl}$ untuk pemangkit tenaga yang digerakkan dengan biogas. Penelitian menggunakan bahan bakar dalam bentuk gas (dalam hal ini adalah biogas) untuk menggerakkan mesin diesel juga telah dilakukan oleh penulis $[9,10,11]$

Hasil kajian literatur ini menunjukkan bahwa penelitian menggerakkan mesin berbahan bakar diesel menjadi berbahan bakar gas mulai banyak 
dilakukan. Hal ini bertujuan untuk mengurangi emisi GRK dari sektor energi. Bahan bakar gas yang umumnya digunakan pada penelitian tersebut adalah Biogas, CNG, dan Bio-CNG. Sejauh penelusuran yang telah dilakukan oleh penulis, belum ditemukan laporan penelitian yang menggunakan LPG untuk menggerakkan mesin diesel. Pada kajian ini dilakukan uji performansi mesin diesel yang dimodifikasi hingga dapat digerakkan oleh bahan bakar LPG. Tujuan penelitian ini adalah untuk mendapatkan performansi mesin diesel dan mendiskusikan karakteritik gas buang dari mesin diesel yang dimodifikasi dan digerakkan dengan bahan bakar gas LPG. Hasil dari penelitian ini diharapkan akan memberikan informasi penting bagi aksi mitigasi pengurangan emisi GRK.

\section{METODE PENELITIAN}

Dalam penelitian ini, sebuah mesin diesel atau mesin compression ignition (selanjutnya disingkat $\mathrm{CI}$ ) yang dibeli dari pasar Indonesia digunakan dalam percobaan. Nama komersial mesin CI adalah KAMA Model YL170F dengan daya plat $2,5 \mathrm{~kW}$ dan $2,8 \mathrm{~kW}$ pada putaran mesin 3000 dan $3600 \mathrm{rpm}$. Jenis mesinnya adalah mesin berpendingin udara satu silinder dengan dimensi stroke dan bore masing-masing $70 \mathrm{~mm}$ dan $55 \mathrm{~mm}$. Berdasarkan spesifikasi ini, maka dikategorikan sebagai mesin CI yang kecil dengan berat $27 \mathrm{~kg}$. Mesin seperti ini biasanya ditemukan oleh petani kecil Indonesia.

\section{Modifikasi Mesin}

Sebuah peralatan eksperimental telah dirancangbangun untuk dapat melakukan penelitian ini. Skema alat uji yang dirancangbangun ditunjukkan pada Gambar 1. Sistem ini terdiri dari satu unit mesin CI, sebuah generator, satu unit rangkaian lampu, tangki LPG, alat pencampur gas, dan alat ukur untuk mengumpulkan data yang diuji. Seperti yang dinyatakan di bagian sebelumnya, mesin CI diuji dalam dua mode operasi yang berbeda. Pada mode pertama, mesin CI diuji tanpa modifikasi. Bahan bakar yang digunakan adalah minyak diesel. Pada mode kedua, karena bahan bakar yang digunakan adalah gas, beberapa modifikasi dilakukan terhadap mesin. Kepala silinder mesin dimodifikasi dengan mengganti nosel dengan busi. Sebuah mixer gas telah dirancang dan dikembangkan untuk mencampur udara segar dengan gas. Di sini, sebuah intake manifold digunakan untuk menyuntikkan campuran ke dalam mesin.

Sinyal sudut engkol digunakan untuk mendeteksi sinyal kecepatan mesin. Sinyal ini digunakan untuk mengatur waktu pembakaran. Regulator gas digunakan untuk mengatur tekanan bahan bakar LPG sebelum disuntikkan ke mesin. Tekanan elpiji saat dicampur dengan udara segar diukur dengan menggunakan manometer. Kecepatan mesin diukur dengan menggunakan tachometer. Kumparan pengapian yang dihubungkan dengan power supply (baterai) dan sinyal sudut engkol digunakan untuk menentukan waktu pembakaran.

Sebuah generator dengan nama komersial Brushless digunakan untuk mensimulasikan beban. Generator yang digunakan adalah jenis self-exciting, 2poles, single phase. Spesifikasi generator adalah sebagai berikut. Rating frekuensi, rating voltage, rating power, dan power factor masing-masing adalah $50 / 60 \mathrm{~Hz}$, 110-240 V, 0,8 - 1,1 kVA, dan 1,0. Listrik dari generator digunakan untuk menyalakan serangkaian lampu yang bisa dioperasikan pada beban 400W dan 800W. Minyak diesel dibeli dari PERTAMINA yang merupakan pengecer minyak milik pemerintah Indonesia. Sebelum digunakan, nilai kalor atau LHV dari minyak diesel diuji dengan menggunakan bom kalorimeter. LHV dan densitas bahan bakar diesel masing-masing adalah 42,64 MJ / kg dan $0,82 \mathrm{~kg} / \mathrm{m} 3$. LPG yang digunakan dalam penelitian ini diproduksi oleh PERTAMINA dan dijual di pasar Indonesia. Bahan bakar ini terdiri dari $30 \%$ 
Propana dan $70 \%$ Butana. Nilai pemanasan dan kerapatan pada atmosfir masingmasing adalah 48,8 MJ/kg dan $1,71 \mathrm{~kg} / \mathrm{m} 3$. Suhu diukur dengan menggunakan termometer jenis KW 06-278 Ksatria dengan kisaran akurasi 0,5\% 1oC. Beban listrik diukur dengan menggunakan Multitaster Meter CD800A. Kecepatan putaran mesin CI diukur menggunakan Tachometer.

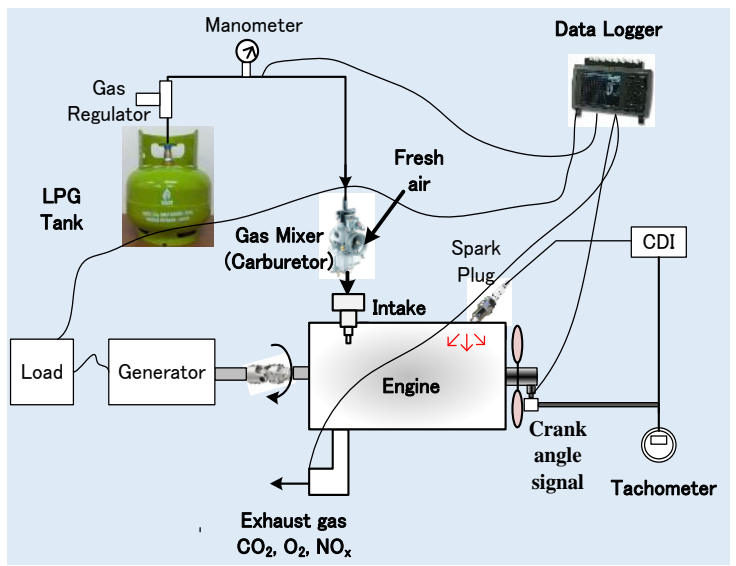

Gambar 1. Skema Alat Pengujian

Pada percobaan mode pertama, mesin CI dijalankan dengan diesel murni. Disini bebannya tetap pada $800 \mathrm{~W}$ dan putaran mesin bervariasi mulai dari 2600 rpm hingga $3.400 \mathrm{rpm}$. Untuk setiap putaran mesin, saat mesin CI dalam kondisi stabil, pengukuran dilakukan selama 5 menit. Parameter yang diukur tenaga listrik, konsumsi bahan bakar, suhu, dan kecepatan mesin. Pada percoban mode kedua, dilakukan modifikasi pada mesin CI. Bahan bakar LPG dari tangki dicampur dengan udara segar di mixer. Tekanan LPG dari tangki diturunkan menjadi 1,8 bar dengan menggunakan regulator gas. Pengukuran parameter yang sama dengan percobaan pertama saat mesin berbahan bakar diesel murni dilakukan. Setiap tes diuji sebanyak tiga kali dan pengukurannya dirata-ratakan.

\section{Formulasi parameter}

Daya yang dihasilkan $P_{E}$ (Watt) dari mesin CI dihitung dengan menggunakan pengukuran voltase dan arus listrik yang dihasilkan oleh generator. Daya dihitung dengan menggunakan persamaan berikut:

$$
P_{E}=V \times I
$$

dimana $V$ [Volt] and $I$ [Ampere] adalah tegangan dan arus yang dihasilkan oleh generator. Parameter selanjutnya adalah efisiensi yang didefinisikan sebagai tenaga listrik yang dihasilkan oleh generator dibagi dengan total energi dari pembakaran bahan bakar di mesin CI. Untuk mode pertama, CI dengan bahan bakar diesel murni, dihitung dengan menggunakan persamaan (2).

$$
\eta=\frac{P_{E}}{\dot{m}_{\text {diesel }} \times L H V_{\text {diesel }}}
$$

dimana $L H V_{\text {diesel }}[\mathrm{kJ} / \mathrm{kg}]$ adalah nilai kalor dari bahan bakar diesel. Pada pengujian mode kedua, saat mesin CI dikonversi menjadi ber bahan bakar LPG, efisiensinya dirumuskan dengan persamaan (3).

$$
\eta=\frac{P_{E}}{\dot{m}_{L P G} \times L H V_{L P G}}
$$

dimana $L H V_{L P G}[\mathrm{~kJ} / \mathrm{kg}]$ dan $\dot{m}_{L P G}[\mathrm{~kg} / \mathrm{s}]$ adalah nilai kalor dan laju aliran massa LPG.

Parameter analysis berikutnya adalah konsumsi bahan bakar spesifik atau sfc $[\mathrm{g} / \mathrm{kWh}]$. Parameter ini adalah rasio konsumsi bahan bakar terhadap energi bermanfaat yang dihasilkan. Disini bisa dilihat berapa gram bahan bakar yang dibutuhkan untuk menghasilkan $1 \mathrm{kWh}$ energi listrik. Untuk pengujian mode pertama, parameter ini dihitung dengan persamaan (4).

$$
s f c=\frac{\dot{m}_{\text {diesel }} \times 10^{3}}{P_{E}}
$$

Sedangkan untuk percobaan mode kedua, digunakan persamaan (5).

$$
s f c=\frac{\dot{m}_{L P G} \times 10^{3}}{P_{E}}
$$


Dengan menggunakan parameterparameter yang telah diformulasikan di atas, kinerja mesin CI yang diuji dapat dianalysis.

\section{HASIL DAN PEMBAHASAN}

Hasilnya akan dibahas di 4 sub bagian, yaitu daya keluaran, efisiensi total, konsumsi bahan bakar spesifik, dan emisi gas buang.

\section{Daya Keluaran}

Gambar 2 menunjukkan daya keluran yang dihasilkan mesin CI sebagai fungsi dari putaran mesin. Pada pengujian ini mesin CI diberi beban $400 \mathrm{~W}$ dan 800 W. Kedua mode pengujian saat berbahan bakar diesel murni dan saat berbahan bakar LPG juga ditampilkan. Karakteristik daya luaran mesin ini ditunjukkan pada gambar. Semakin tinggi putaran maka daya keluaran mesin akan semakin tingi. Kenaikan daya luaran mesin terjadi secara linier. Pada saat beban mesin $400 \mathrm{~W}$, kedua bahan bakar menunjukkan daya keluaran yang sama pada putaran yang sama. Hanya sedikit perbedaan yang terjadi. Dengan kata lain dapat dikatakan bahwa pada beban rendah daya keluaran mesin akan sama baik saat mesin digerakkan dengan minyak diesel atau saat mesin digerakkan dengan gas LPG. Pada beban yang lebih tinggi yaitu $800 \mathrm{~W}$, terjadi sedikit perbedaan daya keluaran mesin antara bahan bakar diesel dan bahan bakar LPG.

Hasil pengujian ini menunjukkan bahwa mesin diesel yang awalnya dirancang untuk beroperasi dengan bahan bakar minyak diesel dapat dimodifikasi menjadi berbahan bakar LPG. Mesin yang dimodifikasi dapat dioperasikan dengan baik dan menghasilkan daya keluaran yang sebanding dengan mesin ketika dioperasikan dengan bahan bakar diesel murni.

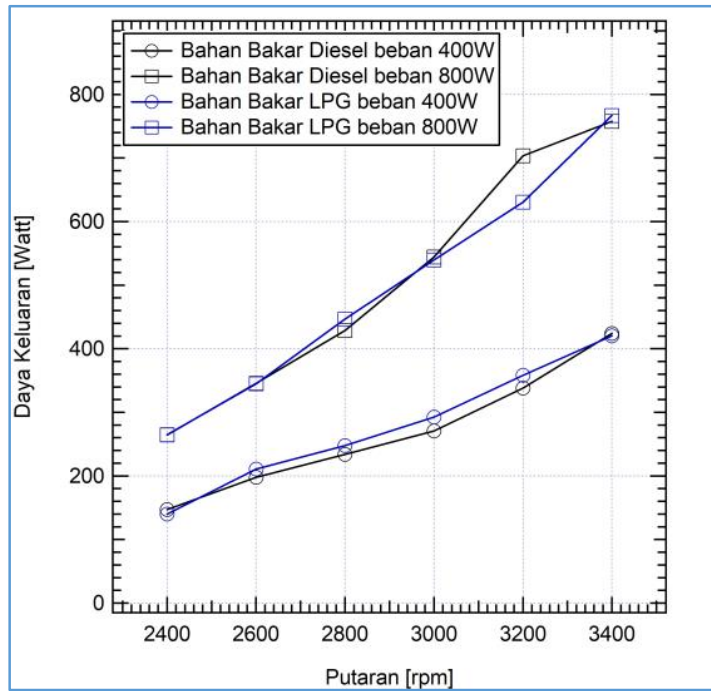

Gambar 2. Daya Keluaran Mesin

\section{Konsumsi bahan bakar spesifik}

Konsumsi bahan bakar spesifik atau $s f c[\mathrm{~kg} / \mathrm{kWh}]$ adalah parameter yang menyatakan seberapa banyak bahan bakar yang dibakar untuk mengasilkan energi berguna dalam satuan kWh. Semakin efektif suatu bahan bakar dikonversikan, maka semakin kecil nilai dari $s f c$.

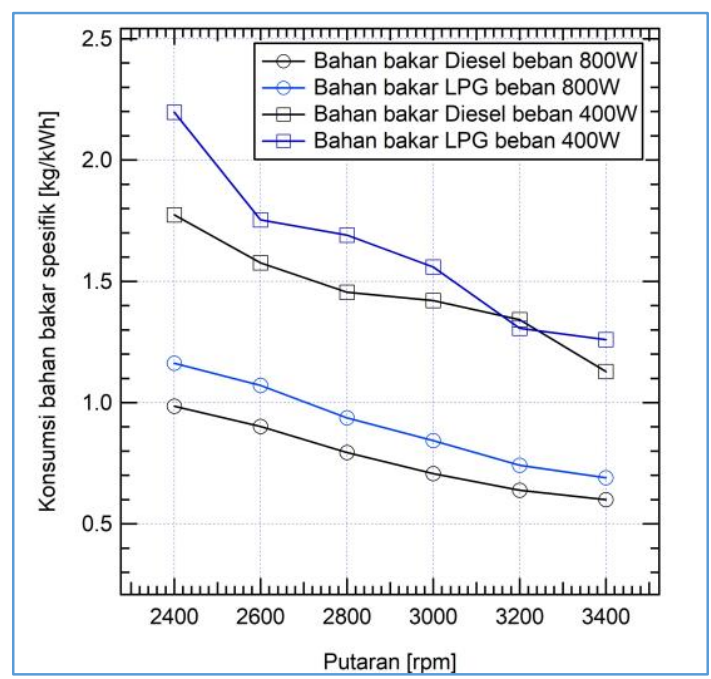

Gambar 3. Konsumsi bahan bakar spesifik

Konsumsi bahan bakar spesifik pada pengujian ini ditampilkan pada Gambar 3. Kedua mode pengujian dan kedua beban yang digunakan ditampilkan pada gambar tersebut. Nilai $s f c$ paling kecil pada pengujian ini adalah $0,59 \mathrm{~kg} / \mathrm{kWh}$ terjadi pada mesin berbahan bakar diesel pada putaran dan beban masing-masing pada $3400 \mathrm{rpm}$ dan $800 \mathrm{~W}$. Sementara nilai 
$s f c$ terbesar adalah $2,19 \mathrm{~kg} / \mathrm{kWh}$ pada pengujian dengan bahan bakar LPG pada putaran dan beban masing-masing 2400 rpm dan $400 \mathrm{~W}$. Nilai $s f c$ bervariasi diantara kedua nilai ini.

Pola yang ditunjukkan gambar adalah semakin tinggi putaran mesin maka semakin rendah nilai $s f c$. Hal ini dikarenakan pada putaran yang lebih tinggi proses pembakaran akan terjadi lebih sempurna dan daya keluaran juga semakin besar. Kombinasi kedua hal ini membuat nilai $s f c$ semakin kecil. Pola ini juga terjadi pada beban yang rendah maupun yang tinggi.

Beban yang diberikan kepada mesin juga mempengaruhi nilai dari $s f c$. Semakin tinggi beban yang diberikan maka nilai $s f c$ justru semakin kecil. Pada saat mesin masih beban rendah maka daya yang dihasilkan juga masih rendah sehingga jika diberi beban untuk menjalankan beban yang ada di mesin disel akan semakin rendah lagi. Daya yang dapat digunakan dan pada akhirnya akan meningkatkan konsumsi bahan bakar spesifik. Pada saat beban cukup tinggi maka daya yang dihasilkan juga semakin tinggi sehingga komsumsi bahan bakar konstan.

Perbandingan nilai $s f c$ pada mesin yang dioperasikan dengan bahan bakar diesel dan degan bahan bakar LPG menunjukkan mesin dengan bahan bakar diesel mempunyai $s f c$ yang sedikit lebih rendah. Nilai ini menunjukkan bahwa $s f c$ dalam pemakaian bahan bakar solar lebih baik dari pada pemakaian bahan bakar LPG. Karena mesin CI yang berjalan dalam mode diesel lebih baik dari pada mesin yang diubah menjadi mesin pengapian percikan menggunakan LPG. Ini karena saat ini mesin CI awalnya dirancang untuk dioperasikan dengan bahan bakar diesel. Semua sistem ini dirancang untuk pengoperasian optimal untuk bahan bakar diesel. Dengan demikian, pengoperasian mesin CI tanpa modifikasi membuat mesin kurang efektif dalam pembakaran menggunakan LPG.

\section{Efisiensi bersih}

Dalam penelitian ini, efisiensi yang dihitung berbeda dengan efisiensi thermal. Dalam efisiensi termal, output akan diukur sebagai daya rem. Disini, efisiensi dihitung dengan menggunakan tenaga output berupa energi listrik yang keluar dari generator. Energi ini adalah energi bersih (netto) yang dihasilkan oleh mesin. Berdasarkan fakta ini maka efisiensi yang akan digunakan disini disebut efisiensi bersih.

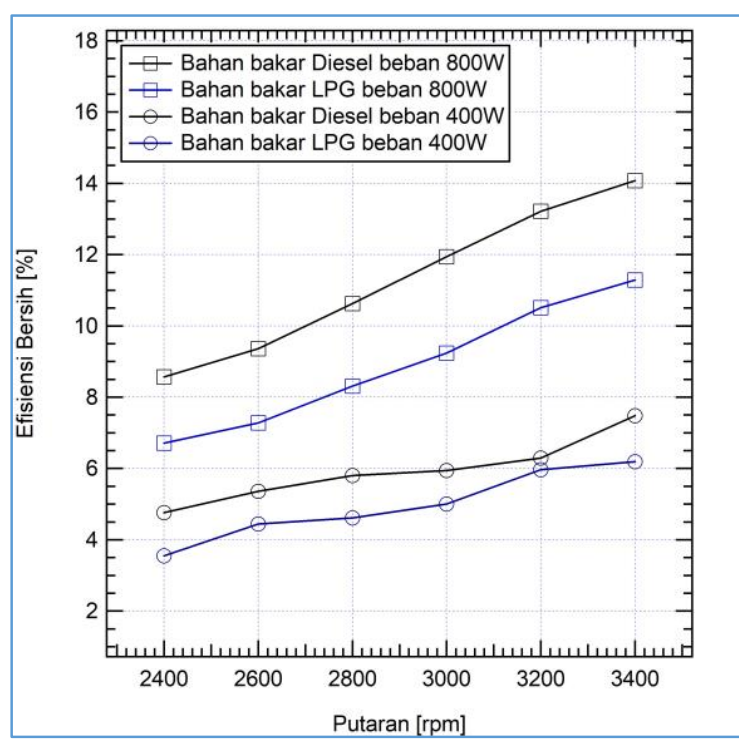

Gambar 4 Efisiensi bersih mesin

Gambar 4 menunjukkan efisiensi bersih mesin pada seluruh pengujian. Pada gambar dapat dilihat bahwa efisiensi akan meningkat dengan meningkatnya putaran dan beban mesin. Sebagai catatan, mesin saat ini memiliki daya $2,5 \mathrm{~kW}$ dan $2,8 \mathrm{~kW}$ pada putaran mesin 3000 dan $3600 \mathrm{rpm}$. Dalam percobaan, beban yang digunakan hanya $400 \mathrm{~W}$ dan $800 \mathrm{~W}$. Jauh di bawah daya yang dimiliki oleh motor diesel yang digunakan dalam pengujian. Dengan demikian, mesin CI sekarang dioperasikan jauh dari efisiensi optimalnya efisiensinya masih jauh dari nilai maksimal yang ada pada motor disel tersebut.

Perbandingan mesin CI dengan solar dan LPG menunjukkan bahwa efisiensi mesin CI yang berjalan pada bahan bakar solar lebih tinggi daripada efisiensi bahan bakar LPG. Pada gambar dapat dilihat bahwa efisiensi bersih mesin dengan 
bahan bakar solar pada beban $400 \mathrm{~W}$, efisiensinya bervariasi dari $4,7 \%$ menjadi $7,4,1 \%$. Pada gambar 7 menunjukan efisiensi bahan bakar LPG dari $3.6 \%$ sampai $6,2 \%$. Sedangkan pada beban 800 W menggunakan bahan bakar solar, memiliki efisiensi lebih tinggi yaitu dari $8,5 \%$ menjadi $14,1 \%$. Pada bahan bakar LPG efisiensinya $6,7 \%$ sampai $11,2 \%$. Nilai ini menunjukkan bahwa efisiensi CI berjalan pada bahan bakar diesel lebih tinggi dari pada bahan bakar LPG. Ini karena mesin CI awalnya dirancang untuk bahan bakar diesel. Semua sistem ini dirancang untuk pengoperasian optimal untuk bahan bakar diesel. Dengan demikian, pengoperasian mesin CI tanpa modifikasi apapun untuk memperbaiki proses pembakaran membuat mesin kurang efisien. Tren serupa juga ditunjukkan oleh konsumsi bahan bakar spesifik.

\section{Emisi gas buang}

Pengujian emisi gas buang mesin diesel bahan bakar LPG parameter yang diamati meliputi kadar $\mathrm{CO}_{2}, \mathrm{CO}, \mathrm{HC}$, dan O2 yang terdapat pada hasil pembakaran bahan bakar.

Tabel 1. Beban 400 Watt

\begin{tabular}{|c|c|c|c|c|}
\hline \multirow{2}{*}{$\begin{array}{l}\text { Putaran } \\
(\mathrm{rpm})\end{array}$} & \multicolumn{4}{|c|}{$\begin{array}{l}\text { Emisi gas buang mesin diesel } \\
\text { bahan bakar LPG }\end{array}$} \\
\cline { 2 - 5 } & $\begin{array}{l}\mathrm{CO}_{2} \\
(\%)\end{array}$ & $\begin{array}{l}\mathrm{CO} \\
(\%)\end{array}$ & $\begin{array}{l}\mathrm{HC} \\
(\mathrm{ppm})\end{array}$ & $\mathrm{O}_{2}(\%)$ \\
\hline 2400 & 0.95 & 2,635 & 849 & 16,43 \\
\hline 2600 & 1.15 & 3,04 & 293 & 16,17 \\
\hline 2800 & 1.35 & 3,165 & 212,5 & 15,7 \\
\hline 3000 & 1.5 & 2,215 & 107,5 & 17,02 \\
\hline 3200 & 1.8 & 1,1 & 67 & 17,79 \\
\hline 3400 & 1.45 & 0,535 & 48,5 & 18,12 \\
\hline
\end{tabular}

Tabel 2. Beban 800 Watt

\begin{tabular}{|c|c|c|c|c|}
\hline $\begin{array}{c}\text { Putaran } \\
\text { (rpm) }\end{array}$ & \multicolumn{4}{|c|}{$\begin{array}{c}\text { Emisi gas buang mesin diesel } \\
\text { bahan bakar LPG }\end{array}$} \\
\hline & $\begin{array}{l}\mathrm{CO}_{2} \\
(\%)\end{array}$ & $\begin{array}{l}\mathrm{CO} \\
(\%)\end{array}$ & $\begin{array}{l}\mathrm{HC} \\
(\mathrm{ppm})\end{array}$ & $\mathrm{O}_{2}(\%)$ \\
\hline 2400 & 1,25 & 3,18 & 1185 & 15,78 \\
\hline 2600 & 1,495 & 3,65 & 524,5 & 15 \\
\hline 2800 & 1,835 & 4,025 & 221,5 & 14,23 \\
\hline 3000 & 2,35 & 2,775 & 136,5 & 14,66 \\
\hline 3200 & 2,6 & 1,645 & 112,5 & 15,39 \\
\hline 3400 & 2,53 & 0,98 & 61,5 & 17,93 \\
\hline
\end{tabular}

Proses pencampuran udara - bahan bakar dimulai dari masuknya bahan bakar ke dalam silinder, kemudian butiran bahan bakar akan menguap dan bercampur dengan udara, proses ini dipengaruhi volatily bahan bakar. Volatily bahan bakar menunjukkan kemampuan bahan bakar untuk dapat menguap. Penambahan beban mengakibatkan peningkatan laju aliran bahan bakar yang masuk ke ruang bakar. Sehingga terjadi peningkatan volatily, yang mengakibatkan semakin meningkatnya kadar emisi gas $\mathrm{CO}_{2}$. Kadar $\mathrm{CO}_{2}$ minimum dihasilkan pada pengujian LPG beban 400 Watt putaran $2400 \mathrm{rpm}$ yaitu sebesar 0,95 $\%$. Sedangkan kadar $\mathrm{CO}_{2}$ maksimum dihasilkan pada pengujian LPG beban 800 Watt putaran $3400 \mathrm{rpm}$ yaitu sebesar 2,53 $\%$.

Emisi gas buang carbon monoksida (CO) terjadi akibat kekurangan oksigen sehingga proses pembakaran berlangsung secara tidak sempurna karena banyak atom $\mathrm{C}$ (karbon) yang tidak mendapatkan cukup oksigen. Akibatnya membentuk gas CO (karbon monoksida). Dari penambahan beban menjadi 800 Watt mengakibatkan penurunan kadar $\mathrm{O}_{2}$, dan mengakibatkan terjadinya peningkatan kadar $\mathrm{CO}$. Hal ini disebabkan pembakaran yang tidak sempurna karna berkurangnya kadar $\mathrm{O}_{2}$ dan seiring dengan meningkatnya laju aliran massa bahan bakar. Kadar CO minimum dihasilkan pada pengujian LPG beban 400 Watt putaran $3400 \mathrm{rpm}$ yaitu sebesar 0,535 $\%$. Sedangkan kadar CO maksimum dihasilkan pada pengujian LPG beban 800 Watt putaran $2800 \mathrm{rpm}$ yaitu sebesar 4,025 $\%$.

Karena pembakaran yang tidak sempurna pada penambahan beban 800 Watt, maka dapat disimpulkan bahwa kadar HC juga akan cenderung meningkat. Kadar HC disebabkan oleh pembakaran yang tidak sempurna pada ruang bakar. Kadar HC minimum dihasilkan pada pengujian LPG beban 400 Watt putaran $3400 \mathrm{rpm}$ yaitu sebesar 48,5 ppm. Sedangkan kadar HC maksimum dihasilkan pada pengujian 
LPG beban 800 Watt putaran $2400 \mathrm{rpm}$ yaitu sebesar $1185 \mathrm{ppm}$.

Kadar oksigen sisa pada pembakaran dengan bahan bakar LPG menunjukkan bahwa tingginya nilai penguapan LPG sehingga oksigen yang digunakan lebih sedikit. Penambahan beban mengakibatkan peningkatan laju aliran bahan bakar. Sehingga semakin tinggi nilai penguapan LPG, sehingga terjadi penurunan nilai kadar $\mathrm{O}_{2}$. Kadar $\mathrm{O}_{2}$ minimum dihasilkan pada pengujian LPG beban 800 Watt putaran $2800 \mathrm{rpm}$ yaitu sebesar $14,23 \%$. Sedangkan kadar $\mathrm{O}_{2}$ maksimum dihasilkan pada pengujian LPG beban 800 Watt putaran 3400 rpm yaitu sebesar $18,12 \%$.

\section{KESIMPULAN}

Kinerja mesin diesel berukuran kecil telah diuji dalam dua bahan bakar berbeda yaitu solar dan LPG. Pada penggunaan bahan bakar solar tidak ada perubahan yang dilakukan pada mesin disel. Pada penggunaan bahan bakar LPG mesin diubah menjadi mesin pengapian percikan dengan mengganti pompa oli menjadi busi. Dilihat dari unjuk kerja mesin CI yang dijalankan pada bahan bakar LPG sebanding dengan putaran mesin pada bahan bakar diesel. Namun, konsumsi bahan bakar spesifik dari mesin CI dengan bahan bakar LPG rata-rata 17,53\% dengan beban $800 \mathrm{~W}$, jika dibandingkan dengan mesin CI yang dijalankan dengan bahan bakar diesel didapat efisiensi mesin CI dengan bahan bakar solar lebih tinggi sebesar 21,43\% dibandingkan dengan mesin CI yang dijalankan dengan bahan bakar LPG. Untuk rata-rata efisiensi dengan beban $400 \mathrm{~W}$ didapat 16,9\% menggunakan bahan bakar solar, sedangkan memakai LPG 11,7\%.

Sedangkan Kadar emisi gas buang $\mathrm{CO}_{2}$ terendah terjadi pada pengujian mesin diesel dengan bahan bakar LPG dengan beban tetap 400 Watt pada putaran mesin $2400 \mathrm{rpm}$ yaitu sebesar $0,95 \%$. Sedangkan kadar emisi gas buang $\mathrm{CO}_{2}$ tertinggi terjadi pada pengujian mesin diesel dengan bahan bakar LPG dengan beban tetap 800 Watt pada putaran mesin $3200 \mathrm{rpm}$ yaitu sebesar $2,6 \%$.

\section{Ucapan Terima Kasih}

Penulis mengucapkan terimakasih kepada Roland Sihombing dan Eko Yohannes Setiawan atas bantuan dalam pengambilan data serta memberikan bantuan dalam melakukan analysis hasil penelitian ini.

\section{DAFTAR PUSTAKA}

[1]. Pemerintah Indonesia, Pereaturan Presiden No 61 Tahun 2011, Tentang Rencana Aksi Nasional Pengurangan Emisi GRK.

[2]. Pemerintah Indonesia, 2016, First Nationally Determined Contribution Republic of Indonesia.

[3]. Kementerian Sumber Daya Mineral dan Energi, 2011, Handbook of Energy and Economic Statistics of Indonesia.

[4]. R. Chandra, V.K. Vijay, P.M.K. Subbarao, T.K. Khura, Performance evaluation of a constant speed IC engine on $\mathrm{CNG}$, methane enriched biogas and biogas, Applied Energy 88 (2011) 3969 - 3977.

[5]. T.H. Lee, S.R. Huang, C.H. Chen, The experimental study on biogas power generation enhanced by using waste heat to preheat inlet gases, Renewable Energy 50 (2013) 342 - 347.

[6]. N. Homdoung, N. Tippayawong, N. Dussadee, Performance and emissions of modified small engine operated on producer gas, Energy Conversion and Management 94 (2015) 286292.

[7]. C. Poompipatpon, K. Cheenkachorn, A modified diesel engine for natural gas operation: 
Performance and emission tests, Energy 36 (2011) 68626866.

[8]. I.D. Bedoya, S. Saxena, F.J. Cadavid, R.W. Dibble, M. Wissink, Experimental evaluation of strategies to increase the operating range of a biogasfueled HCCI engine for power generation, Applied Energy 94 (2012) 618-629.

[9]. H. Ambarita, Performance and emission charcteristics of small diesel engine run in dual-fuel (dieselbiogas) mode, Case Studies in Thermal Engineering 10 (2017) 179-191.

[10].H. Ambarita, E.P. Sinulingga, M. KM. Nasution, H. Kawai, Performance and emissions of a small compression ignition engine run on dual-fuel mode (diesel-raw biogas), IOP Conference Series: Materials Science and Engineering 180 (2017) 012025.

[11].H. Ambarita, T.I. Widodo, and D.M. Nasution, A numerical study on combustion process in a small compression ignition engine run in dual-fuel mode (diesel biogas), Journal of Physic: Conference Series 801(1) (2017) 012095. 